Boletín de la Sociedad Geológica Mexicana

VOLUMEN 66, NÚM. 3, 2014, P. 541-551

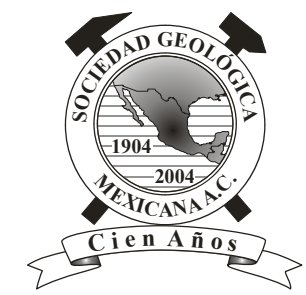

\title{
Inland dunes fauna and flora from Paleolake Irritila in the Comarca Lagunera, Coahuila, northern Mexico
}

\author{
Alexander Czaja ${ }^{1, *}$, Manuel R. Palacios-Fest ${ }^{2}$, José Luis Estrada-Rodríguez ${ }^{1}$, \\ Ulises Romero Méndez ${ }^{1}$, Jorge A. Alba Ávila ${ }^{1}$ \\ ${ }^{1}$ Facultad de Ciencias Biológicas, Universidad Juárez del Estado de Durango, 35010 Gómez Palacio, Durango, México. \\ ${ }^{2}$ Terra Nostra Earth Sciences Research, LLC Tucson, Arizona 85740-7195 U.S.A. \\ *aaczaja@hotmail.com
}

\begin{abstract}
For over a decade the Chihuahuan Desert has been considered as a hotspot of biodiversity. The diverse aquatic ecosystems, especially, are (and were) rich in mollusk species. The dunes of the Comarca Lagunera, Coahuila, Mexico, are of major importance due to the well-preserved remains of animals and plants in a paleolake that covered a vast area in the region. This paper is the first report of the paleolimnological investigations of the Paleolake Irritila ecosystems in northern Mexico. We determined more than 28 species of gastropods, bivalves, ostracods, algae and one aquatic plant. The dunes contain one of the richest and most diverse fauna of the late Quaternary of northern Mexico. The fossils indicate a permanent but shallow lake with moderate salinity and alkalinity (pH) higher than 8.5, most likely around 10. Most of the mollusks are distributed outside Mexico and restricted to northern latitudes (northern United States and Canada). Several of them are endemic to the southern United States (Florida, Nevada, and Texas). For the first time in North America, using the local fauna and flora preserved in dune sediments, we try to reconstruct the paleoenvironmental conditions in northern Mexico during the late Quaternary.
\end{abstract}

Keywords: Paleolake, inland dunes, Pleistocene mollusk fauna, northern Mexico.

Resumen

Desde hace más de una década el Desierto Chihuahuense está considerado como un hotspot de biodiversidad. Especialmente los diversos ecosistemas acuáticos contienen (y contenían) un alto número de especies de moluscos. Las dunas de la Comarca Lagunera, Coahuila, México tienen una gran importancia, ya que contienen bien preservados restos de una fauna y flora de un paleolago que cubrió una extensa parte de esta región. Este artículo es el primer relato de las investigaciones paleolimnológicas de los ecosistemas del Paleolago Irritila en el norte de México. Durante los trabajos fueron determinadas 28 especies de gasterópodos, bivalvos, ostrácodos, algas y una planta acuática lo que convierte las dunas de la Comarca Lagunera en uno de los sitio más diversos con fauna pleistocénica en el norte de México. Los fósiles indican un lago permanente pero no muy profundo con una salinidad moderada y una alcalinidad $(\mathrm{pH})$ mayor de 8.5, más probable alrededor de 10. Gran parte de los moluscos tienen hoy en día una distribución fuera de México en el sur de Estados Unidos y varios de ellos son endémicos en Florida, Nevada y Texas. Por primera vez en el norte de América tratamos de reconstruir mediante la fauna y flora preservada en dunas las condiciones paleo-ambientales en el norte de México durante el Cuaternario tardio.

Palabras clave: Paleolago, dunas, fauna de moluscos pleistocénicos, norte de México. 


\section{Introduction}

For a long time lake sediments have been known as archives of the past because they keep an accurate record of their own history that, in many cases, allow the reconstruction of the paleoenvironments and paleoclimate not only of the lakes themselves but also the region's paleoecological conditions (Lang, 1994). Detailed analysis of macro- and microscopic remains of plants and animals from literally thousands of paleolakes have generated, mostly in Europe, nearly complete series of glacial/ interglacial cycles of the Pleistocene, documenting the evolution of vegetation and paleoclimate in that part of the world (Lang, 1994). By contrast, the Pleistocene faunas and floras of the Americas are not as well-known; hence, this continent has not yet produced a detailed reconstruction of paleoenvironments and complex changes in the vegetation during this part of the Quaternary. The growing database of North America's desert areas is gradually improving our archives of paleontological records from paleolakes, especially in the large Chihuahuan and Sonoran deserts (Catto and Bachhuber, 2000; Palacios-Fest et al., 2002; Castiglia and Fawcett, 2006; Metcalfe, 2006; Chávez-Lara et al., 2012; and others).

Metcalfe (2006) presents an overview of the late Quaternary great deserts of northern Mexico. She presents a summary of climate change data from the Chihuahuan and Sonoran Desert regions and the Trans-Mexican Volcanic Belt from the Middle Pleistocene to the Holocene. To date, a few remains of ancient lake sediments in the great deserts of northern Mexico have been identified mostly from geological-sedimentary drilling (Castiglia and Fawcett, 2006; Chávez-Lara et al., 2012; Roy et al., 2010, 2012). Research primarily focuses on the reconstruction of paleoenvironments through ostracod analysis. Paleolake Babícora near the Sierra Madre Occidental is, to date, the most well investigated place in the Chihuahuan Desert, where profiles and cores of lacustrine sediments contain diatoms, ostracods and pollen representing approximately the last 65000 years (Metcalfe et al., 2002; Ortega-Ramírez et al., 1998; Palacios-Fest et al., 2002; Chávez-Lara et al., 2012).

In January 2012, we found in the dunes of the Comarca Lagunera, Coahuila, Mexico, abundant gastropods, bivalves, ostracods, algae, bones and teeth of reptiles/amphibians fish vertebrae and remains of aquatic plants. These investigations were conducted in two of several places where samples included eolian (sand dunes) and lacustrine sediments of an ancient lake that occupied most of the drainage basin in the geographic center of the Laguna Region (Figure 1). Due to its great size, of approximately $15000 \mathrm{~km}^{2}$, Paleolake Irritila was one of the largest lakes in North America and reached almost the size of modern Lake Erie in the United States. The remains of its extensive sediments are well defined and visible in satellite images.

For the first time in the Americas, we describe the rich and diverse paleofauna and paleoflora from inland dunes of an ancient lake. Fossil preservation is excellent. Based upon diversity and abundance, the fossil material offers a unique opportunity to reconstruct Paleolake Irritila's lacustrine ecosystems prior to the abrupt climatic change in northern Mexico at the end of the Pleistocene, a change that introduced the modern xeric vegetation.

The determination of the fauna and flora of Paleolake Irritila and its first paleoecological interpretation are the main objectives of this report. We also will present a short description of the dune sediments and their possible origin and then, propose the direction of our future research in the fascinating environments that occur in the Comarca Lagunera, Mexico. To achieve this goal we formed a multidisciplinary team of internationally renowned scientists, some of them co-authors of this paper. Paleolake Irritila has been named by the authors to honor the early inhabitants of the land.

\subsection{Regional context}

The Laguna Region is located in the western part of the Chihuahuan Desert in the states of Coahuila and Durango and is formed by a semi-desert plain at an altitude between $1000-1200$ meters above sea level. Its name comes from the ancient shallow lakes formed by the Nazas and Aguanaval rivers, which existed until the construction of an embankment dam in the second half of the twentieth century. Paleolake Irritila covered the central part of the Laguna Region, a huge drainage basin of tectonic origin of approximately $15000 \mathrm{~km}^{2}$ (Figure 1).

The vegetation is dominated by xerophytic scrub, even though grasslands and thorn forest (mesquite) are common. The high concentration of salts in the soils of this region determines the existence of a dominant halophytic vegetation in the landscape. Desert scrub plants including rosetophyllous and microphyllous scrublands occur in a patchy pattern, composed mainly of desert scrub (Larrea tridentata) and halophytes. The climate is arid, very dry with an average annual rainfall of $224 \mathrm{~mm}$ and an average annual temperature of $21^{\circ} \mathrm{C}$. Summer temperatures can reach 48 ${ }^{\circ} \mathrm{C}$; whereas in the winter temperatures may drop to $-8^{\circ} \mathrm{C}$.

\section{Materials}

On April 2012 two sites, the Bilbao and Acatita Dunes, were sampled for geological analysis (Figure 1). Two kilogram pilot-samples were dry-screened at the Universidad Juarez laboratory using a set of two sieves, fractions 0.5 and $0.3 \mathrm{~mm}$. The sediments of the Bilbao Dunes were analyzed using a low power stereoscopic microscope to identify major mineral components and their percent abundance. All sediments were treated with hydrochloric acid (10\% solution) to test for the presence of carbonates. However, the sediments of the Acatita Dunes were sent to 


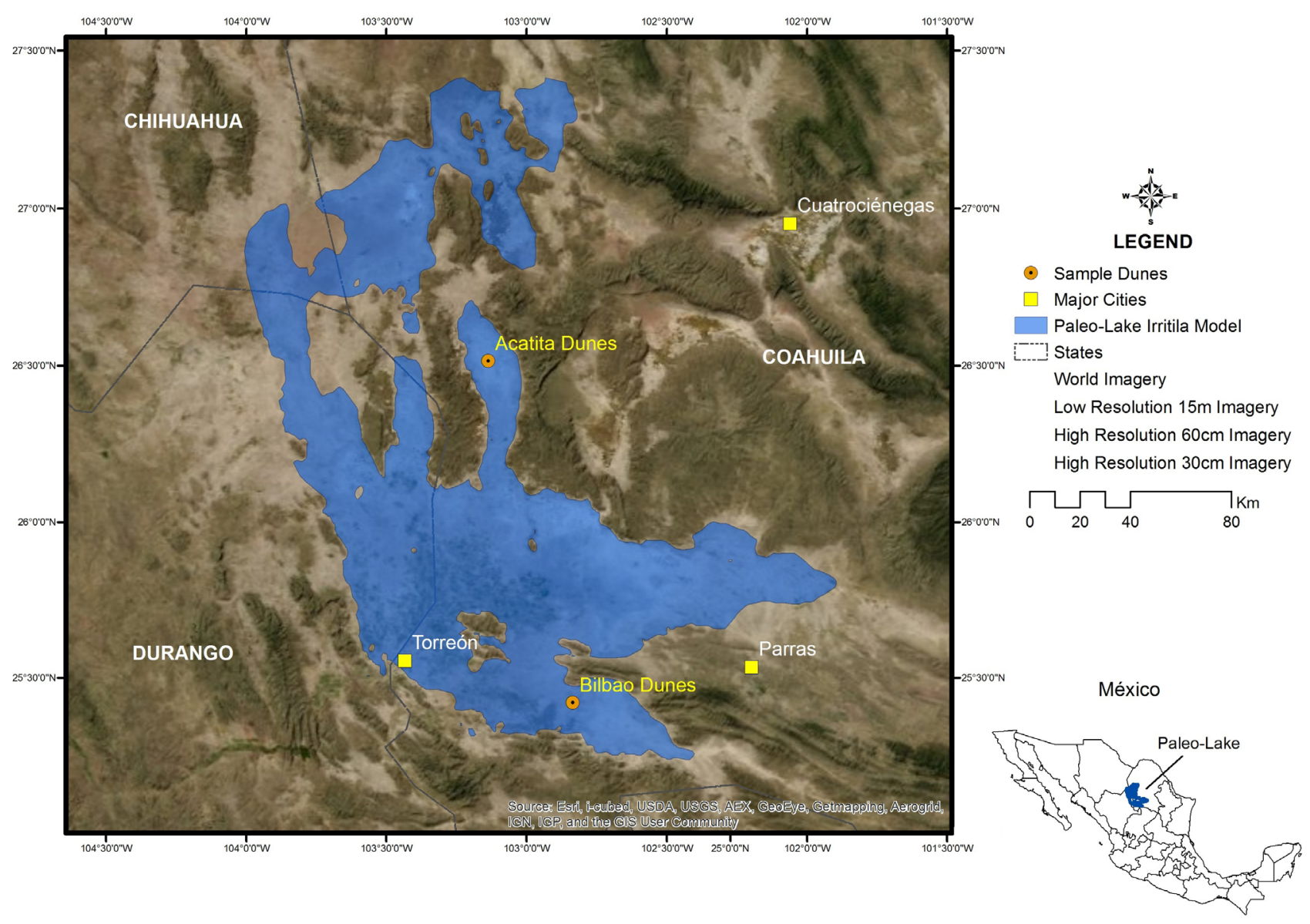

Figure 1. Location of the Paleolake Irritila in the Comarca Lagunera, Mexico. The paleolake model is based on the distribution of lacustrine sediments and the content of its fauna.

Met-Mex Peñoles, Mining Company laboratory in Torreon, Coahuila to obtain the chemical content due to the more complex mineralogical composition.

The fossil fauna and flora were selected from the screened sampled with tweezers using a stereoscope and posteriorly the specimens were cleaned of sediment. A fraction of the samples were sent to Terra Nostra Earth Sciences Research, LLC in Tucson, Arizona, for ostracod analysis. All specimens of ostracods and algae were determined to the species level. Some gastropods (Cochliopidae) were sent for determination to Dr. Robert Hershler from the Smithsonian Institution, Washington. Dr. Amy Wethington, Chowan University, Murfreesboro and Dr. Robert Dillon, Jr., Charleston, participated in identifying species of the genus Physa (Physidae).

Other gastropods and the bivalves were determined using the reference collection of the Universidad Juarez, Faculty of Biology, Durango State, and with the aid of specialized literature and the existing monographs (cited in references). The fossil fauna and flora are housed at the Faculty of Biology of the Universidad Juarez, Durango State (Collection: UJED-MAL-IRIT-101-345).
A preliminary model of Paleolake Irritila was created using ArcGIS v. 9.3.1. (ESRI, 2008) and STRM DEM 3 (USGS, 2000), geographic digital programs for mapping and geographic data analysis (Figure 1). Our database relies on the distribution of lacustrine sediments and eolian deposits (dunes) in the central part of the Comarca Lagunera, Durango and Coahuila States, Mexico.

\section{Results}

\subsection{Fauna and Flora}

The fauna and flora of Paleolake Irritila and its surroundings are the main objective of this report. Pilot samples from Acatita and Bilbao Dune sediment were selected for the study of ostracods, gastropods, bivalves, calcareous algae, fish and reptile vertebrae, as well as the remains of aquatic vegetation (Table 1).

\subsubsection{Gastropods}

Gastropods are the most abundant macrofossils in the 
Table 1. Taxonomic list of mollusk, crustaceae and plants from the dunes of Paleolake Irritila, Comarca Lagunera, Coahuila, Mexico with the abundances of species (number of specimens) in sediment samples from Acatita and Bilbao dunes.

\begin{tabular}{|c|c|c|}
\hline Taxa & Acatita Dunes & Bilbao Dunes \\
\hline \multicolumn{3}{|l|}{ Physidae } \\
\hline Physa acuta Draparnaud & 12 & 3 \\
\hline \multicolumn{3}{|l|}{ Planorbidae } \\
\hline Ferrissia sp. 1 (spec. novum?) & 4 & $\mathrm{x}$ \\
\hline Ferrissia fragili s Tryon & 3 & 1 \\
\hline Biomphalaria sp. & 2 & $\mathrm{x}$ \\
\hline Planorbella cf. duryi Wetherby & 25 & $\mathrm{x}$ \\
\hline Planorbella sp. ("scalaris"- type) & 13 & 2 \\
\hline \multicolumn{3}{|l|}{ Succineidae } \\
\hline Succinea sp. vel Oxyloma sp. & 1 & $\mathrm{x}$ \\
\hline \multicolumn{3}{|l|}{ Cochliopidae } \\
\hline Pyrgulopsis sp. 1 (spec. novum) & 22 & $\mathrm{x}$ \\
\hline Tryonia sp. 1 & 3 & 2 \\
\hline Tryonia sp. 2 (spec. novum) & 44 & $\mathrm{x}$ \\
\hline Tryonia sp. 3 (spec. novum) & $\mathrm{x}$ & 8 \\
\hline \multicolumn{3}{|l|}{ Pupillidae } \\
\hline Pupoides albilabris (C.B. Adams) & 1 & - \\
\hline \multicolumn{3}{|l|}{ Sphaeriidae } \\
\hline Sphaerium cf. sulcatum Lamarck & 24 & $\mathrm{x}$ \\
\hline Sphaerium $s p$ & 15 & 3 \\
\hline Pisidium compressum Prime & 5 & $\mathrm{x}$ \\
\hline Pisidium sp. & 2 & 2 \\
\hline \multicolumn{3}{|l|}{ Unionidae } \\
\hline Anodonta sp. & 9 & $\mathrm{x}$ \\
\hline \multicolumn{3}{|l|}{ Potamogetonacae } \\
\hline Potamogeton cf. pectinatus Lamarck & 1 & $\mathrm{x}$ \\
\hline \multicolumn{3}{|l|}{ Ostracoda } \\
\hline Limnocythere ceriotuberosa Delorme & 153 & 42 \\
\hline Cyprideis salebrosa van den Bold & 32 & 18 \\
\hline Fabaeformiscandona caudata Kaufmann & 15 & 5 \\
\hline Candona patzcuaro Tressler & 12 & 11 \\
\hline Candona punctata Furtos & 6 & 11 \\
\hline Ilyocypris bradyi G.O.Sars & $\mathrm{x}$ & 8 \\
\hline \multicolumn{3}{|l|}{ Algae } \\
\hline Chara vulgaris $\mathrm{L}$. & 36 & 26 \\
\hline Chara canescens Desv. and Lois & 22 & 3 \\
\hline Chara globularis Thuill & 32 & 24 \\
\hline Chara filiformis Hertzsch & 4 & $\mathrm{x}$ \\
\hline
\end{tabular}

dunes of Paleolake Irritila. The analyses conducted at the biological laboratory of the Universidad Juarez, State of Durango and the Zoology Laboratory of the Smithsonian Institution in Washington show at least 12 species of gastropods, including the pulmonates Physidae, Planorbidae, two genera of Cochliopidae (Tryonia and Pyrgulopsis) and the land families Pupillidae and Succineidae. The land snails present are Pupoides albilabris (C.B. Adams, 1841) and Succinea sp./Oxyloma sp.

The Physidae are represented only by one species of Physa Draparnaud, a freshwater genus with sinisterly coiled shells that occurs in lakes and rivers and feeds mainly from algae. Regardless of the abundant literature, the Physiidae are a complex group of aquatic gastropods that require a revision of their systematics and taxonomy due to the countless synonyms currently known. Wethington and Lydeard (2007), Wethington et al. (2009) and Dillon et al. (2002) have accomplished a great deal of this revision in proposing to re-organize the genus Physa into six groups with 13 species. However, their investigations are based on molecular phylogeny and for the most part do not include the morphology of shells, which account for the majority of the remains found in the geologic record.

We identified the Acatita Dunes specimens as Physa acuta Draparnaud, 1805 (Figure 2, a-d), a cosmopolitan species with a great ecophenotipic plasticity and many synonyms like Physa virgate (Gould, 1855), P. heterostropha (Say, 1817), P. integra (Haldeman, 1841), P. cubensis (Pfeiffer, 1839) y P. mexicana (Philippi, 1841) and others. Our material corresponds well with Paraense and Pointier's (2003) description of Physa acuta; they studied topotipic specimens. The only difference is that as fossils the specimens from Acatita are discolored (like most Pleistocene mollusks). Physa acuta was originally described from French material and it was accepted for a long time that the species comes from the old World. Dillon et al. (2002) were the first that postulated a possible North American origin of Physa acuta and the Pleistocene records of Acatita Dunes are the best evidence of this hypothesis. Dillon (2000) reported investigations on Physa acuta showing that the species lives in many lakes almost entirely on aquatic plants, strongly preferring Potamogeton pectinatus Linné, 1753. Therefore, it is no coincidence that we have found endocarps of this aquatic plant together with shells of Physa acuta in Acatita Dunes.

The genus Tryonia Stimpson, 1865 is represented by two new species that belong morphologically to the groups of Tryonia clathrata Stimpson, 1865 and Tryonia circumstriata (Leonard and Ho, 1960). Hershler (2001) compiled the best monograph on the systematics of Tryonia, identifying 18 modern species with a disjunctive distribution in the southwestern part of North America and Central America (Guatemala). Recently, Hershler et al. (2011) added 13 new species of Tryonia found in springs of the Chihuahuan Desert (Mexico and USA). At the Acatita Dunes we found a form with very prominent axial ribs (Figure 2, h) apparently morphologically related to Tryonia clathrata Stimpson; to date, it is a species endemic to the southwestern United States (southern Nevada). The genus Tryonia appeared for the first time with several species in the Miocene of South America (Wesselingh, 2006). Some of them morphologically belong to the precursors of the "clathrata"-group. In the Pliocene Tryonia spiralistriata Wesselingh, 1996, very similar to the recent $T$. clathrata, lived already in Central America (Guatemala) and in the Pleistocene members of the "clathrata"-group reached Mexico and the United States. Wesselingh et al. (1999) interpreted this temporal succession as a northward migration of Tryonia introduced by migratory birds following water resources. By contrast, Pilsbry (1934) found some snails in the Pliocene beds of the 


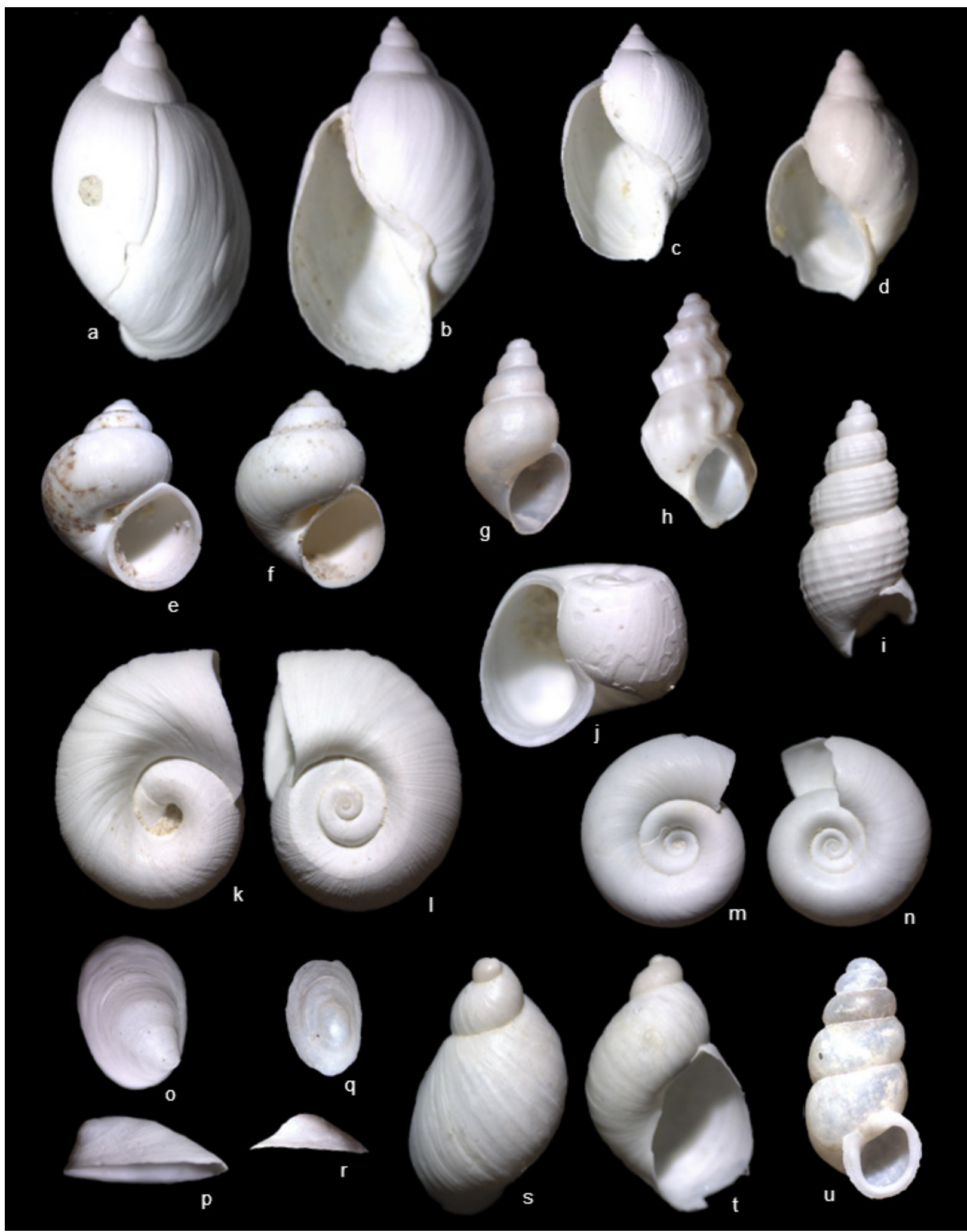

Figure 2. a, b: Physa acuta Draparnaud, Acatita Dunes (shell length: $15 \mathrm{~mm}$ ). c: Physa acuta Draparnaud, Acatita Dunes (shell length: $12 \mathrm{~mm}$ ). d: Physa acuta Draparnaud, Acatita Dunes (shell length: $11 \mathrm{~mm}$ ). e: Pyrgulopsis sp. 1 (spec. novum), Acatita Dunes, Pleistocene edge (shell length: $4.1 \mathrm{~mm}$ ). f: Pyrgulopsis sp. 1 (spec. novum), Acatita Dunes, Pleistocene edge (shell length: $4.2 \mathrm{~mm}$ ). g: Tryonia sp. 1, Bilbao Dunes (shell length: $2.9 \mathrm{~mm}$ ). h: Tryonia sp. 2 (spec. novum, group "clathrata"), Acatita Dunes, Pleistocene edge (shell length: $3.4 \mathrm{~mm}$ ). i: Tryonia sp. 3 (spec. novum, group "circumstriata"), Acatita Dunes, Pleistocene edge (shell lenght: $3.6 \mathrm{~mm}$ ). j: Planobella sp. (scalaris-type), Acatita Dunes (shell width: $7.1 \mathrm{~mm}$ ). k, 1: Planobella sp. (cf. P. duryi Wetherby), Acatita Dunes (shell diameter: $12.3 \mathrm{~mm}$ ). m, n: Biomphalaria sp., Acatita Dunes (shell length: $6.1 \mathrm{~mm}$ ). o, p: Ferrissia sp. 1 (spec. novum?), Acatita Dunes (shell lenght: $3.9 \mathrm{~mm}$ ). q, r: Ferrissia fragilis Tryon, Acatita Dunes (shell length $2.8 \mathrm{~mm}$ ). s, t: Succinea sp. vel Oxyloma sp., Acatita Dunes (shell length: $9.9 \mathrm{~mm}$ ). u: Pupoides albilabris (C.B. Adams), Acatita Dunes (shell length: $3.7 \mathrm{~mm}$ ). 
Kettleman Hills, California, that closely resemble Tryonia (he described them as Hydrobia). These Pliocene Tryonia gastropods from California, however, have smooth shells and do not belong to the "clathrata"-group. The history of the genus Tryonia is still not well understood but the new species from Acatita brings new biogeographical information to the evolution of this genus.

At Bilbao Dunes we found a form very similar in size, shape and ornamentation to Tryonia circumstriata (Leonard and Ho, 1960) (Figure 2, i). Today, the species is only known from a single site in Texas, United States. This species was originally described as Calipyrgula circumstriata from the Late Pleistocene. Later, the species was placed as a member of the genus Tryonia (Hershler, 2001). This new species from Bilbao seems to have their precursors in the Miocene of South America, as well. The description of the Paleolake Irritila new species of Cochliopidae (Tryonia and Pyrgulopsis) (Figure 2, e, f, h) will be reserved for another paper.

Other small aquatic pulmonates found in the dunes include the tribe Ancylini, of the family Planorbidae. The Ancylini are characterized by conical shells forming a limpet that are not spirally coiled. Two species of Ferrissia (Walker, 1903) occur at the Acatita Dunes. Like Physa, the taxonomy of the genus Ferrissia is complex and contains more than 20 species in North America. Basch (1963) revised the group and recognized only five species for the genus. Nevertheless, the distinction of these five species was still very difficult in practice. The most recent molecular phylogenetic revision of the genus confirms great ecophenotipic plasticity and documents only two species: Ferrissia rivularis (Say, 1817) and F. fragilis (Tryon, 1863) for North America (Walther et al., 2010). Some of the shells from Acatita Dunes are very thin and fragile, $2-3.5 \mathrm{~mm}$ long, slightly elevated and with an apex in the right-posterior quadrant (Figure 2, q, r). These features coincide well with the description of Ferrissia fragilis by Walther et al. (2010). According to these authors the species prefers small ponds as a habitat and is often able to survive dry conditions. Four shells from Acatita Dunes with an extremely twisted apex to the right are probably a new species of Ferrissia (Figure 2, o, p). However, based on the ecophenotipic plasticity of Ferrissia more specimens will be required to make a formal description.

Large sized gastropods from the dunes were identified as Planorbella sp. (Figure 2, k, 1), in all details similar to Planorbella duryi (Wetherby, 1879), a species that includes several subspecies of variable size and shape. To date, Planorbella duryi is endemic to Florida (Thompson, 1984). Occurrence in Paleolake Irritila of other species also known from Florida and affiliated to Planorbella scalaris (Jay, 1839) (Figure 2, j) suggest that we have in Acatita two endemic species of Planorbella; both tolerate slightly brackish conditions (Figure 2, j).

Only two terrestrial species were identified from the Acatita Dunes: Succinea sp. vel Oxyloma sp. (Figure 2, s, t) and Pupoides albilabris (C.B. Adams, 1841) (Figure 2, u). Oxyloma and Succinea may only be distinguished by soft parts since the shells are almost indistinguishable. The calciphilous and arid-tolerant species Pupoides albilabris occurs already as a habitat generalist in many places, frequently on bare ground (Hubricht, 1985). In northern Mexico we have observed this species also living on grass near small water bodies.

\subsubsection{Bivalves}

The Pelecypoda from both dune fields of Paleolake Iritila included abundant, diverse, and well preserved small and large bivalve shells. In this investigation we identified at least six species of Sphaeriidae and Unionoidea.

The most abundant shells found at the Acatita Dunes are small ( $8-17 \mathrm{~mm}$ wide) and belong to the genus Sphaerium (Figure 3, a, b). None of the 12 species reported from North America (Herrington, 1962) has a combination of characters similar to those from Acatita. The specimens resemble Sphaerium sulcatum (Lamarck, 1818) and Sphaerium striatinum (Lamarck, 1818) but these species develop thicker shells than those from Acatita. Herrington (1962), however, in his review of the North American Sphaeriidae emphasizes "... a great lack of uniformity in size and outline of the shells..." for Sphaerium striatinum. The same author also mentions differences in shape between river and lake specimens. A new species or the shells from Acatita are still within the range of intraspecific variation of Sphaerium striatinum or Sphaerium sulcatum, respectively. Based upon its size (up to $17 \mathrm{~mm}$ ) the material from the Acatita Dunes is closer to Sphaerium sulcatum; therefore, in this paper it is identified as Sphaerium sp. cf. S. sulcatum. The species is widely distributed from Canada to the northern United States where it mainly lives in small lakes, rivers and streams (Herrington, 1962). Other smaller but not so common shells of the same genus were determined as Sphaerium sp. (Figure 3, c, d).

In addition, the Acatita Dunes also include small (1.5 $-3.6 \mathrm{~mm}$ ) but very thick shells that were determined as Pisidium compressum Prime, 1852 (Figure 3, e, f). Pisidium is the most common genus of bivalves in North America (Herrington, 1962). Today, Pisidium compressum lives in a diversity of habitats, preferring shallow sandy bottoms with rooted vegetation, and is restricted to permanent water.

Other bivalves found in the dunes of Acatita include large $(>25 \mathrm{~mm}$ ) shells of the suprafamily Unionoidea. Highly fragmented, a few almost complete and well preserved valves were recovered and identified as Anodonta sp.

\subsubsection{Ostracods}

Six ostracod species were identified from the Acatita Dunes sediments (Table 1). The ostracods present are Limnocythere ceriotuberosa Delorme, 1967 (the most abundant); Cyprideis salebrosa (van den Bold, 1963), the second most abundant; Fabaeformiscandona caudata (Kauffmann, 1900); Candona patzcuaro Tressler, 1954; Candona punctata Furtos, 1933; and Ilyocypris bradyi Sars, 


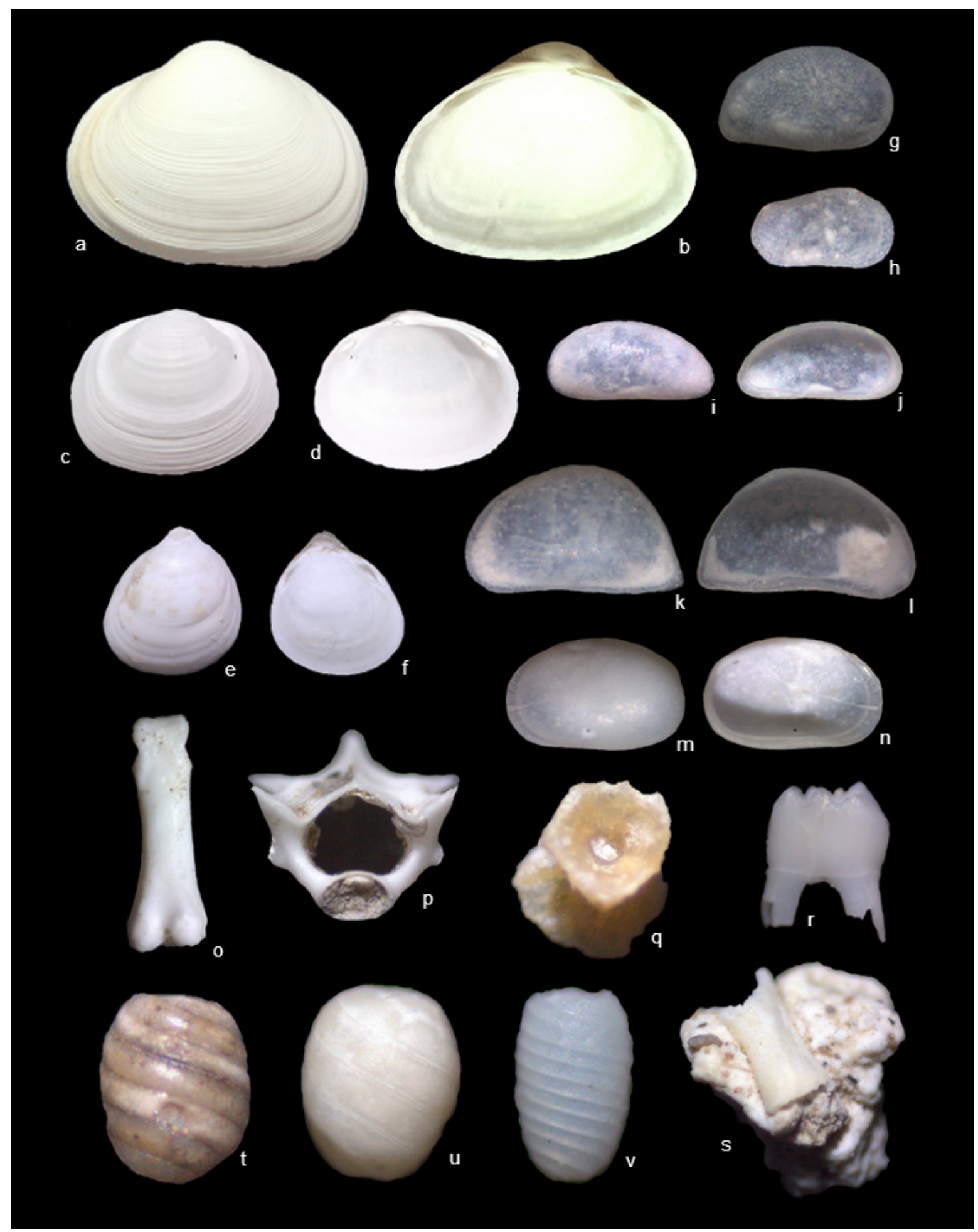

Figure 3. a, b: Sphaerium cf. sulcatum Lamarck, Acatita Dunes (shell length: $16.3 \mathrm{~mm}$ ). c, d: Sphaerium sp., Acatita Dunes (shell length: 6.8 mm). e, f: Pisidium compressum Prime, Acatita Dunes (shell length: $3.2 \mathrm{~mm}$ ). g: Cyprideis salebrosa van den Bold, juvenile, external lateral view, right valve, Acatita Dunes (length: $1.2 \mathrm{~mm}$ ). h: Limnocythere ceriotuberosa Delorme, adult female, external lateral view, right valve, Acatita Dunes (length: $0.7 \mathrm{~mm}$ ). i: Fabaeformiscandona caudata Kaufmann, juvenile, external lateral view, left valve, Acatita Dunes (length: 1.1 mm). j: Fabaeformiscandona caudata Kaufmann, juvenile, internal lateral view, left valve, Acatita Dunes (length: $1.1 \mathrm{~mm}$ ). k: Candona punctata Furtos, adult female, external lateral view, left valve, Acatita Dunes (length: $1.5 \mathrm{~mm}$ ). 1: Candona punctata Furtos, adult female, internal lateral view, left valve, Acatita Dunes (length: $1.5 \mathrm{~mm}$ ). m: Cyprideis salebrosa van den Bold, adult female, external lateral view, left valve, Bilbao Dunes (length: $1.2 \mathrm{~mm}$ ). n: Cyprideis salebrosa van den Bold, adult female, internal lateral view, right valve, Bilbao Dunes (length: $1.2 \mathrm{~mm}$ ). o: Undetermined bone, Acatita Dunes (length: $3.5 \mathrm{~mm}$ ). p: Vertebrae, Acatita Dunes (diameter: $3 \mathrm{~mm}$ ). q: Fish vertebrae, Acatita Dunes (diameter: $1.8 \mathrm{~mm}$ ). r: Mammal tooth, Acatita Dunes (length: $2.8 \mathrm{~mm}$ ). s: Bone in sediment, Bilbao Dunes (length: $2.5 \mathrm{~mm}$ ). t: Chara globularis Thuill., Bilbao Dunes (height: $0.8 \mathrm{~mm}$ ). u: Chara vulgaris L., Acatita Dunes (height: 0.7 $\mathrm{mm}$ ). v: Chara filiformis Hertzsch, Acatita Dunes (height: $0.4 \mathrm{~mm}$ ). 
1890. The ostracod assemblage indicates variable salinity conditions as eurytopic (wide tolerance) species dominate. Salinity tolerance exceeds $10000 \mathrm{mg} \mathrm{L}^{-1}$ total dissolved solids (TDS) (Forester et al., 2005). By contrast, the rare occurrence of other species suggest less hostile conditions, as indicated by $C$. punctata, a species restricted to a salinity range below $1000 \mathrm{mg} \mathrm{L}^{-1} \mathrm{TDS}$.

\subsubsection{Calcareous Algae}

In addition to ostracods, we identified the female gametangia (gyrogonites) in calcareous algae (Charales). Charophytes are a small group that evolved in continental waters from dilute to alkaline conditions. The female gametangia produce a calcareous exoskeleton called gyrogonites; the only part preserved in the geologic record. Calcareous algae occur in calm, lentic (low energy) lakes and ponds; occasionally, in streams. Brackish water is also a preferred environment (Allen, 1950). Ecologically, the Charales promote clear water, attract fish and stabilize the substrate where they live. They are more abundant in shallow waters (less than $60 \mathrm{~cm}$ depth). The algae range in size from 30 to $46 \mathrm{~cm}$; whereas the gyrogonites are less than $5 \mathrm{~mm}$ (Allen, 1950). An important characteristic is that charophytes grow between the early spring and late summer and are known as pioneer colonizers (Allen, 1950). Together, ostracods and charophytes are excellent paleoecological indicators.

The calcareous algae at Acatita Dunes include Chara vulgaris L., 1753; Chara globularis Thuille, 1799, Chara filiformis Hertzsch, 1855 and Chara canescens Desv. and Lois., 1810. C. vulgaris and C. globularis, the most abundant species, are eurytopic (Wood, 1967). By contrast, C. canescens is a rare species restricted to alkaline and saline conditions, whereas $C$. filiformis prefers diluted to moderately saline waters (Wood, 1967). All four species prefer a $\mathrm{pH}$ range between 7.8 and 8.5 , with the exception of C. canescens that thrives in waters with $\mathrm{pH}$ values between 8.7 and 9.4 (Langangen, 2010). The algal assemblage identified from Acatita Dunes indicates alkaline conditions with a $\mathrm{pH}$ greater than 8.5 , probably 10 , consistent with the ostracod assemblage.

\subsubsection{Fish, amphibian, and reptile bones}

Some vertebrate remains, small fish, amphibians and reptile bones in a good state of preservation were also found at the Acatita and Bilbao Dunes (Figure 3, o, p, q, $\mathrm{s})$. The description of this material will be reserved for further investigation. Fossil bones from the Pleistocene are not easily distinguished from modern bones that are also abundant on the dune surfaces. To prevent confusion we only collected specimens from the indurated dunes (Figure 3, s).

\subsubsection{Aquatic plant}

In contrast with the diverse faunal remains found at the
Acatita Dunes only a single endocarp of an aquatic plant, Potamogeton, was found. Based upon its shape, large size (4.3 mm long, $3.3 \mathrm{~mm}$ wide), and rounded dorsal crest, the specimen was identified as Potamogeton sp. cf. $P$. pectinatus. Potamogeton illinoensis Morong, 1880 develops a similar endocarp; however, this species is smaller and has a longer dorsal rib.

Usually, the genus includes freshwater species although some may tolerate brackish water conditions. Potamogeton pectinatus tolerates higher salinity as other species of the genus. The species is a cosmopolitan and common plant in shallow and permanent water bodies ( $<2.5 \mathrm{~m}$ water depth). It tolerates high $\mathrm{pH}$ and alkaline waters, lives submerged and rooted. In many submerged communities Potamogeton pectinatus is associated with Chara canescens (RojasMoreno and Novelo-Retana, 1995) and this calcareous algae was also found in samples from the Acatita Dunes. This aquatic vegetation is typical of inland brackish lakes, salt marshes, as well as coastal lagoons often accompanied by Zannichellia, Najas and Ceratophyllum. The species is reported for the first time from Coahuila and Durango States.

\subsection{Mineralogy}

\subsubsection{Bilbao Dunes}

The sediments from the dunes of Bilbao consist of a range of minerals including quartz, feldspar, apatite, micas, amphibole (hornblende), pyroxenes and sporadically grains of magnetite and probably hematite. Remarkable also is the presence of salt (halite) that coincides with the presence of the genus Suaeda, a halophyte, in the dunes. The sediments are fine-grained, and well sorted between $0.1-0.4 \mathrm{~mm}$. Grains are very slightly rounded, reflecting a relatively short distance of transport from their provenance. A fluvial origin from the Aguanaval (southwest) and Nazas (west) rivers is shown by the mineralogical composition. Igneous rocks from the nearby Sierra Madre Occidental are the main source of sediments; however, the surrounding limestone beds in the basin may have contributed some materials, as well. In Bilbao (not in Acatita) we observed some old dunes of Late Wisconsin age in addition to the young dunes of Recent age. These occasional old dunes are more compacted than the more recent ones. The Bilbao and Acatita dune areas differ in that the Bilbao Dunes generally contain more vegetation as a result of stabilization.

\subsubsection{Acatita Dunes}

In spite of their homogenous appearance, the sediments from the Acatita Dunes could not be easily identified macroscopically; hence, chemical analysis was conducted using X-ray diffraction, fluorescence scans RX and Nitton XRF gun to determine the mineral composition (Table 2). Based upon the results the Acatita Dunes are mainly formed of calcium carbonate (34\%) followed by quartz (18\%) and other silicates (feldspars, micas) representing approximately 
Table 2. Chemical content of sediments of the dunes of Acatita, Coahuila, Mexico. The chemical analysis was conducted using X-ray diffraction, X-ray fluorescence scans and Niton XRF gun.

\begin{tabular}{|c|c|c|}
\hline Mineral & Chemical Formula & $\%$ (approx.) \\
\hline Calcite & $\mathrm{CaCO}_{3}$ & $34.71 \%$ \\
\hline Quartz & $\mathrm{SiO}_{2}$ & $12.11 \%$ \\
\hline Tarasovite & $\mathrm{Na} \mathrm{KAl}_{8}(\mathrm{Si}, \mathrm{Al})_{16} \mathrm{O}_{40}(\mathrm{OH})_{8} \cdot 2 \mathrm{H}_{2} \mathrm{O}$ & $9.09 \%$ \\
\hline Talc & $\mathrm{Mg}_{3} \mathrm{Si}_{4} \mathrm{O}_{10}(\mathrm{OH})_{2}$ & $7.16 \%$ \\
\hline $\begin{array}{l}\text { Sodium Magnesium } \\
\text { Aluminum Fluoride Silicate }\end{array}$ & $\mathrm{Na} \mathrm{Mg}_{3} \mathrm{Al} \mathrm{Si}_{3} \mathrm{O}_{10} \mathrm{~F}_{2}$ & $6.63 \%$ \\
\hline Silicon Oxide & $\mathrm{SiO}_{2}$ & $5.90 \%$ \\
\hline $\begin{array}{l}\text { Sodium Aluminum Silicate } \\
\text { Hydrate }\end{array}$ & $\mathrm{Na}_{2} \mathrm{O}-\mathrm{Al}_{2} \mathrm{O}_{3}-\mathrm{SiO}_{2}-\mathrm{H}_{2} \mathrm{O}$ & $5.75 \%$ \\
\hline $\begin{array}{l}\text { Calcium Magnesium } \\
\text { Aluminum Silicate Hydroxide }\end{array}$ & $\mathrm{Ca}\left(\mathrm{Mg}_{2} \mathrm{Al}\right)\left(\mathrm{Al}_{2.8} \mathrm{Si}_{1.2}\right) \mathrm{O}_{10}(\mathrm{OH})_{2}$ & $5.40 \%$ \\
\hline Mica & $\mathrm{K}-\mathrm{Mg}-\mathrm{Fe}-\mathrm{Al}-\mathrm{Si}-\mathrm{O}-\mathrm{H}_{2} \mathrm{O}$ & $4.49 \%$ \\
\hline Hisingerite & $\mathrm{Fe}_{2} \mathrm{Si}_{2} \mathrm{O}_{7} \times \mathrm{H}_{2} \mathrm{O}$ & $2.87 \%$ \\
\hline Almandine & $\mathrm{Fe}_{3}\left(\mathrm{Al}_{2} \mathrm{Si}_{3} \mathrm{O}_{12}\right)$ & $2.09 \%$ \\
\hline Portlandite & $\mathrm{Ca}(\mathrm{OH})_{2}$ & $1.06 \%$ \\
\hline Dolomite & $\mathrm{Ca}\left(\mathrm{Ca}_{0.17} \mathrm{Mg}_{0.83}\right)\left(\mathrm{CO}_{3}\right)_{2}$ & $0.87 \%$ \\
\hline $\begin{array}{l}\text { Sodium Hydrogen Aluminum } \\
\text { Silicate }\end{array}$ & $\mathrm{Na}_{0.5} \mathrm{H}_{0.5}\left(\mathrm{AlSi}_{2} \mathrm{O}_{6}\right)$ & $0.70 \%$ \\
\hline Cristobalite & $\mathrm{SiO}_{2}$ & $0.63 \%$ \\
\hline Magnesium Iron Oxide & $(\mathrm{MgO})_{0.593}(\mathrm{FeO})_{0.407}$ & $0.55 \%$ \\
\hline
\end{tabular}

$35 \%$. Absence of calcium sulfates is intriguing in spite of the occurrence of gypsum in the surroundings of Acatita Valley. It is likely that gypsum and other salts occur in the underlying strata.

\section{Discussion}

The dunes of Paleolake Irritila contain one of the richest and most diverse mollusk fauna of the late Quaternary from northern Mexico. Our first results permitted to infer, at a glance, the paleoenvironmental conditions of a huge paleolake in the region, suggesting that it will require a more detailed analysis. Over twenty-eight species of invertebrates, vertebrates, algae, and angiosperms (selected from samples of only $2 \mathrm{~kg}$ of sediment) indicate a permanent but shallow lake (Sphaerium, Physa and Potamogeton) with moderate salinity $\left(\leq 1000 \mathrm{mg} \mathrm{L}^{-1}\right.$, ostracods) and alkalinity $(\mathrm{pH})$ higher than 8.5 , most likely around 10 . An algal mat covered the bottom of the lake and formed with aquatic angiosperms the base of a productive ecosystem. The dunes' ecology indicates that mollusks, ostracods, and bivalves lived together in this habitat near the shoreline while the two terrestrial species (Pupoides albilabris and Succinea sp./Oxyloma sp.) were rinsed into the lake.

Today, almost all mollusks identified from the dunes of Comarca Lagunera are extinct in the region. Most of them are distributed outside Mexico and restricted to northern latitudes (northern United States and Canada). Several of them are endemic to the southern United States (Florida, Nevada, and Texas). This is of major significance to understand the taxa evolutionary and chronological history.

The remains of fish, amphibians, and reptiles in the dune sediments support a rich and diverse fauna in and around the ancient lake. Determination of vertebrates will also offer insight on the vegetation and regional climatic conditions around Paleolake Irritila. The paleolake's size implies that among other climatic factors intense precipitation affected the Laguna Region during the Late Pleistocene. In addition, the modern distribution of most of species found in the Acatita and Bilbao dunes show that northern Mexico was subject to cold-wet conditions at this time. Presence of fluvial sediments forming "gravel channels" near the dunes is in good agreement with our preliminary interpretation. These "gravel channels", not dated yet, contain a similar fauna to that of the dunes. We interpreted these deposits as river overflow due to heavy precipitation. Similar "gravel-" and "sand channels" have been reported around the sand dunes in the Boneville basin, Utah, United States, dated after 12500 and prior to $1100014 \mathrm{C}$ years B.P. (Oviatt et al., 2003). Chronologically, these features correlate with our estimated age for the Acatita gravels. Paleoclimatic evidence from the American Southwest and northern Mexico indicate that the region became warmer and drier through the Holocene (comprehensive summary in: OrtegaRamírez et al., 2003). Many of the other water bodies in the Chihuahuan and Sonoran desert region have a similar evolution (Palacios-Fest et al., 2002; Palacios-Fest, 2008).

To date, the site's geologic history is not well-known and the fauna is not dated. Its geomorphological and geological context indicates that the inland dunes of the Comarca Lagunera were formed during the late Quaternary (probably between the latest Pleistocene (late Wisconsinian age) and early/middle Holocene), characterized by a Late Pleistocene fauna that possibly extended into part of the earliest Holocene. However, the last episode of dune formation is still ongoing, implying aridification is occurring today. The occurrence of mollusk species in the Comarca Lagunera today restricted to northern latitudes suggests that the fauna is Pleistocene in age. It is common that Pleistocene faunal and floral assemblages lack modern comparisons. We may compare the ecological behavior of Pleistocene and recent species but we should not search for equivalent recent ecosystem in northern Mexico. Pleistocene ecosystems had not only different but also singular environmental conditions currently absent. For example, Pleistocene lakes were very dynamic and mostly short-lived systems that changed their physical and chemical conditions as well as their biocenosis during their life-cycle. The biotic communities of the dunes of Acatita and Bilbao reflect a "window" that probably opened briefly prior to the start of the lake's desiccation.

To conclude, there are no records of rich Pleistocene molluscan faunal assemblages in northern Mexico with which to compare the Paleolake Irritila fauna. The only site with a detailed micropaleontological chronology is Paleolake Babícora near the Sierra Madre Occidental (Metcalfe et al., 2002; Ortega-Ramírez et al., 1998; Palacios-Fest et al., 2002). Lacustrine sediments representing approximately the last 65000 years lack mollusks and the last 12000 years B.P. are generally very poor in fossils (Chávez-Lara et al., 2012). 
The principal aim of our future research will be to obtain a sediment core to get a vertical section of the Pleistocene sequence. We will continue our surface exploration and sampling within Paleolake Irritila and in a second paper we will compare and correlate the faunal assemblages with rich Pleistocene sites of the Late Pluvial of the American Southwest (Oklahoma, Kansas, Texas, Arizona, and New Mexico) and also with some central Mexican sites. We are encouraged to continue with our research to accomplish this goal during a second phase.

\section{Acknowledgements}

The authors are grateful to Dr. Robert Hershler, Smithsonian Institute, Washington, D.C., Dr. Amy Wethington, Chowan University, Murfreesboro and Dr. Robert Dillon, Jr., Charleston, for their support in the determination of some gastropods. We would like to thank Laurentina Villegas, Met-Mex-Peñoles Mining Company, Torreón, Mexico, for the chemical analysis of samples from Acatita Dunes.

\section{References}

Allen, G.O., 1950, British Stoneworts (Charophyta): Arbroath, Great Britain, Haslemere Natural History Society, T. Buncle and Company, $52 \mathrm{p}$.

Basch, P.F., 1963, A review of the Recent freshwater limpet snails of North America (Mollusca: Pulmonata): Bulletin of the Museum of Comparative Zoology at Harvard College, 129, 399-461.

Castiglia, P., Fawcett, P.J., 2006, Large Holocene lakes and climate change in the Chihuahuan Desert: Geology, 34, 113-116.

Catto, N., Bachhuber, F.W., 2000, Aeolian geomorphic response to climate change: an example from the Estancia Valley, central New Mexico. in McLaren, S., Kniveton, D. (eds.), Linking Climate Change to Land Surface Change: Kluwer Academic Press, 171-192.

Chávez-Lara, C.M., Roy, P.D., Caballero, M.M., Carreño, A.L., Lakshumanan, C., 2012, Lacustrine ostracods from the Chihuahuan Desert and inferred Late Quaternary paleoecological conditions: Revista Mexicana de Ciencias Geológicas, 29 (2), 422-431.

Dillon, R.T.Jr., 2000, The Ecology of Freshwater Molluscs: United Kingdom, Cambridge University Press, 509 p.

Dillon, R.T.Jr., Wethington, A.R., Rhett, J.M., Smith, T.P., 2002, Populations of the European freshwater pulmonate Physa acuta are not reproductively isolated from American Physa heterostropha or Physa integra: Invertebrate Biology, 121 (3), 226-234.

ESRI, 2008, ArcGIS 9.3.1., Shuttle Radar Topography Mission 3 arcsecond (Environmental Scientific Research Institute). Redlands, California, USA.

Forester, R.M., Smith, A.J., Palmer, D.F., Curry, B.B., 2005, North American Non-Marine Ostracods Database (NANODe), Version 1: Electronic document, available at $<\mathrm{http}: / / \mathrm{ww} w . k e n t . e d u /$ NANODe>.

Herrington, H.B., 1962, A revision of the Sphaeriidae of North America: Miscellaneous Publications, Museum of Zoology, University of Michigan, 118, $74 \mathrm{p}$.

Hershler, R., 2001, Systematics of the North and Central American Aquatic Snail Genus Tryonia (Rissooidea: Hydrobiidae): Smithsonian Contributions to Zoology, 612, 1-53.

Hershler, R., Liu H.P., Landye, J.J., 2011, New species and records of spring snails (Caenogastropoda: Cochliopidae: Tryonia) from the Chihuahuan Desert (Mexico and United States), an imperiled biodiversity hotspot: Zootaxa, 3001, 1-32.

Hubricht, L., 1985, The distributions of the native land mollusks of the Eastern United States: Fieldiana, Zoology New Series, 24, 199 p.

Lang, G., 1994, Quartäre Vegetationsgeschichte Europas. Methoden und Ergebnisse: New York, Gustav Fischer Verlag Jena, Stuttgart, 464 p.

Langangen, A., 2010, Some Charophytes (Charales) collected on the island of Evia, Greece in 2009: Flora Mediterranae, 20, 149-157.

Metcalfe, S.E., 2006, Late Quaternary environments of the northern deserts and central transvolcanic belt of Mexico: Annals of the Missouri Botanic Gardens, 93, 258-273.

Metcalfe, S., Say, A., Black, S., McCulloch, R., O'Hara, S., 2002, Wet conditions during the Last Glaciation in the Chihuahuan Desert, Alta Babícora Basin, Mexico: Quaternary Research, 57, 91-101.

Ortega-Ramírez, J.R., Valiente-Banuet, A., Urrutia-Fucugauchi, J., Mortera-Gutiérrez, C.A., Alvarado-Valdez, G., 1998, Paleoclimatic changes during the Late Pleistocene-Holocene in Laguna de Babícora, near the Chihuahuan Desert, México: Canadian Journal of Ears Sciences, 35, 1168-1179.

Ortega-Ramírez, J., Maillol, J.M., Bandy, W., Valiente-Banuet, A., Urrutia Fucugauchi, J., Mortera-Gutiérrez, C.A., Medina-Sánchez, J., Chacón-Cruz, G.J., 2003, Late Quaternary evolution of alluvial fans in the Playa, El Fresnal region, northern Chihuahua desert, Mexico: Palaeoclimatic implications: Geofísica Internacional, 43 (3), 445-466.

Oviatt, C.G., David, B., Madsen, D.B., Schmitt, D.N., 2003, Late Pleistocene and early Holocene rivers and wetlands in the Bonneville basin of western North America: Quaternary Research, 60, 200-210.

Palacios-Fest, M.R., 2008, Younger Dryas Ostracod Paleoecology of Scholle Cienega, Abo Arroyo, New Mexico: Tucson, Arizona, U.S.A. Terra Nostra Earth Sciences Research, TNESR Report 08-10.

Palacios-Fest, M.R., Carreño, J.R., Ortega-Ramírez, A.L., AlvaradoValdéz, G., 2002, A paleoenvironmental reconstruction of Laguna Babícora, Chihuahua, Mexico based on ostracod paleoecology and trace element Shell chemistry: Journal of Paleolimnology, 27, 185-206.

Paraense, W., Pointier, J.P., 2003, Physa acuta Draparnaud, 1805 (Gastropoda: Physidae): a study of topotypic specimens: Memorias do Instituto Oswaldo Cruz, 98, 513-517.

Pilsbry, H.A., 1934, Mollusks of the fresh-water Pliocene beds of the Kettleman Hills and neighboring oil fields. California: Procceedings of the Academy of Natural Sciences of Philadelphia, 86, 541-570.

Rojas-Moreno, J., Novelo-Retana, A., 1995, Flora y vegetación acuáticas del lago de Cuitzeo, Michoacán, México: Acta Botánica Mexicana 31, 1-17.

Roy, P.D., Caballero, M., Lozano, R., Ortega, B., Lozano, S., Pi, T., Israde, I., Morton, O., 2010, Geochemical record of Late Quaternary paleoclimate from lacustrine sediments of paleo-lake San Felipe, western Sonora Desert, Mexico: Journal of South American Earth Sciences, 29, 586-596.

Roy, P.D., Caballero, M., Lozano, S., Morton, O., Lozano, R., Jonathan, M.P., Sánchez, J.L., Macías, M.C., 2012, Provenance of sediments deposited at paleolake San Felipe, western Sonora Desert: Implications to regimes of summer and winter precipitation during last 50 cal kyr BP: Journal of Arid Environments, 81, 47-58.

Thompson, F.G., 1984, An identification manual for the freshwater Snails of Florida: University Press of Florida, $94 \mathrm{p}$.

USGS, 2000, Shuttle Radar Topography Mission 3 arc-second, Denver, available at: $<\mathrm{http}: / / \mathrm{www} 2 . j p l . n a s a . g o v / \mathrm{srtm} />$.

Walther, A.C., Burch, J.B., Ó Foighil, D., 2010, Molecular Phylogenetic Revision of the Freshwater Limpet Genus Ferrissia (Planorbidae: Ancylinae) in North America Yields Two Species: Ferrissia (Ferrissia) rivularis and Ferrissia (Kincaidilla) fragilis: Malacologia, 53 (1), 25-45.

Wesselingh, F.P., 2006, Molluscs from the Miocene Pebas Formation of Peruvian and Colombian Amazonia: Scripta Geologica, 133, 19-290. 
Wesselingh, F.P., Cadée, G.C., Renema, W.R., 1999, Flying high: on the airborne dispersal of aquatic organisms as illustrated by the distribution histories of the gastropod genera Tryonia and Planorbarius: Geologie en Mijnbouw, 78, 165-174.

Wethington, A.R., Lydeard, C., 2007, A molecular phylogeny of Physidae (Gastropoda: Basommatophora) based on mitochondrial DNA sequences: Journal of Molluscan Studies, 73, 241-257.

Wethington, A.R., Wise, J., Dillon, R.T.Jr., 2009, Genetic and morphological characterization of the Physidae of South Carolina, with description of a new species: Nautilus, 123, 282-292.
Wood, R.D., 1967, Charophytes of North America: A guide to the species of Charophyta of North America, Central America and the West Indies. Text largely after Monograph of the Characeae: Stella's Printing, West Kingston, Rhode Island, $72 \mathrm{p}$.

Manuscript received: December 31, 2013.

Corrected manuscript received: April 13, 2014.

Manuscript accepted: April 20, 3014. 